\title{
CAUSES FOR CULLING AND REPRODUCTIVE SYSTEM DISORDERS IN JERSEY COWS IN THE REPRODUCTIVE PERIOD
}

\section{PRZYCZYNY BRAKOWANIA ORAZ ZABURZENIA ZDROWOTNE UKŁADU ROZRODCZEGO KRÓW RASY JERSEY}

\author{
Department of Animal Breeding and Product Quality Assessment, Poznań University \\ of Life Sciences, Poland \\ ${ }^{1}$ Computer Lab, Poznań University of Life Sciences, Poznań, Poland \\ 2 Department of Ruminant Science, West Pomeranian University of Technology, Szczecin, Poland
}

\begin{abstract}
Streszczenie. Celem pracy była analiza przyczyn brakowania oraz określenie zaburzeń zdrowotnych układu rozrodczego krów rasy jersey w jednym ze stad Wielkopolski. Badaniami objęto 331 krów rasy jersey. Materiał badawczy z lat 2010-2015 dotyczył dokumentacji oceny wartości użytkowej krów mlecznych, programu zarządzania stadem AfiFarm i zeszytu wizyt lekarza weterynarii. Dane źródłowe dotyczyły przyczyn brakowania krów oraz zaburzeń zdrowotnych układu rozrodczego występujących w okresie rozmnażania (tj. od wycielenia do skutecznego zacielenia). Powody ubywania krów podzielono według kryterium stosowanego przez Polską Federację Hodowców Bydła i Producentów Mleka. W badaniach określono udział przyczyn brakowania krów oraz ustalono frekwencję poszczególnych zaburzeń zdrowotnych układu rozrodczego krów w okresie rozmnażania, przy uwzględnieniu podziału na grupy pierwiastek i wieloródek. Najczęstszymi przyczynami brakowań krów rasy jersey były jałowość i choroby układu rozrodczego. Natomiast u krów tej rasy wśród występujących w okresie rozmnażania zaburzeń układu rozrodczego najczęściej stwierdzano występowanie zapalenia błony śluzowej macicy. Pod względem statystycznym nie wykazano istotnego związku między grupą wiekową krów (pierwiastek i wieloródek), a częstotliwością występowania określonych zaburzeń układu rozrodczego. Zmniejszenie częstości występowania schorzeń układu rozrodczego u krów rasy jersey w okresie rozmnażania jest możliwe przy ciągłym doskonaleniu czynników środowiskowych oddziałujących na zwierzęta.
\end{abstract}

Key words: Jersey cows, culling, reproductive system diseases.

Słowa kluczowe: jersey, brakowanie, choroby dróg rodnych.

\section{INTRODUCTION}

At present the most important breeding objective in herds of high-producing dairy cows is to improve functional traits of the animals, which considerably contribute to a reduction of milk production costs, resulting in greater profits from this type of animal production. Currently the intention of cattle breeders and milk producers is to have cows characterised

Corresponding author - Adres do korespondencji: Ireneusz R. Antkowiak, Department of Animal Breeding and Product Quality Assessment, Poznań University of Life Sciences, Złotniki, Słoneczna 1, 62-002 Suchy Las, Poland, e-mail: irekantk@up.poznan.pl 
by longevity resulting from their good health status and high lifetime milk yield exceeding 100 thousand $\mathrm{kg}$ milk. Assessment of culling causes may be a useful tool verifying the effectiveness of breeding efforts in a herd. It is assumed that the optimal annual culling rate for cows should be approx. $20 \%$, although in high-producing herds it may be slightly higher. Causes for culling of cows may be divided into voluntary and involuntary and into economic and biological. In the opinion of Zając-Mazur (2007), economic causes include those, which lead to an increased breeding value of the herd, while biological causes result in unexpected losses, e.g. calving problems or incidence of disease. Sterility and reproductive system disorders were primary culling causes.

In terms of the worldwide population of dairy purpose cattle the Jersey breed ranks second (after Black-and-White cattle). In comparison to large dairy breeds Jersey cows produce comparable amounts of fat and protein per head, while in relation to body weight unit they yield identical amounts of milk as well as $30-50 \%$ more fat and $20-30 \%$ more protein (Skrzypek 1994). In comparison to other breeds the Jersey cattle are also exceptional in terms of their advantageous functional traits. However, the analysis of culling causes and specific causes of reproductive system disorders in cows of this breed are of interest not only to Jersey cattle breeders.

The aim of this study was to analyse culling causes and to determine reproductive system disorders in Jersey cows in the reproductive period in a herd kept in the Wielkopolska region (Poland).

\section{MATERIAL AND METHODS}

Analyses were conducted on 331 Jersey cows coming from the Wiktorowo farm, belonging to the Iwno Stud. The material for analyses was collected for the years 2010-2015 from the performance testing documentation of dairy cows, the AfiFarm herd management programme and the veterinary inspection records. Source data concerned culling causes and reproductive health disorders in cows during their reproductive period (i.e. from calving to successful fertilisation). Causes for culling were divided according to the criterion applied by the Polish Federation of Cattle Breeders and Dairy Farmers (PFCBDF). The following reproductive system disorders were diagnosed in cows during their reproductive life: endometritis, uterine tumors, hypoovarianism, abortion, pyometra, ovarian cysts and polycystic ovaries.

In this study the shares of individual culling causes in the total number of culled cows were determined and the incidence rates of individual reproductive system disorders in cows during their reproductive period were calculated in terms of the division into the groups of primiparous and multiparous cows.

Statistical analyses were performed using the SAS ver. 9.4 package (2015). The FREQ procedure was applied to calculate frequencies. Fisher's exact test and Cramer's coefficient $V_{\text {CRAMER }}$ were also used in the calculations. Fisher's test was applied to determine the probability of a specific distribution in comparison to the values in the table. The hypothesis on a lack of a dependence between the analysed factors was tested. The power of dependencies between the tested components was estimated using the $V_{\text {CRAMER }}$ statistic. 


\section{RESULTS}

Table 1 presents shares of individual causes of culling in relation to the total number of culled cows. A total of 176 cows were culled in the years of the study. It was found that sterility and reproductive system diseases accounted for the highest percentage of culling cases (34.66), followed by metabolic disorders and diseases of the alimentary system (14.20), with udder diseases and casualties accounting for $9.66 \%$ cases each and locomotor system diseases and other causes each responsible for $7.39 \%$, respectively. In turn, infectious diseases and old age were least frequent culling causes $(0.57 \%)$.

Table 1. Shares of culling causes (according to the criterion applied by PFCBDF) for Jersey cows in the analysed years in the total number of culled animals

Tabela 1. Udział przyczyn ubycia (według kryterium stosowanego przez PFHBiPM) krów rasy jersey ze stada w analizowanych latach, w odniesieniu do sumarycznej liczby osobników usuniętych

\begin{tabular}{|c|c|c|}
\hline $\begin{array}{l}\text { Culling cause } \\
\text { Przyczyna brakowania }\end{array}$ & $\mathrm{N}$ & $\begin{array}{l}\text { Percentage } \\
\text { Procent }\end{array}$ \\
\hline $\begin{array}{l}\text { Sale for further rearing } \\
\text { Sprzedaż do dalszego chowu }\end{array}$ & 12 & 6.82 \\
\hline $\begin{array}{l}\text { Low productivity } \\
\text { Niska wydajność }\end{array}$ & 12 & 6.82 \\
\hline $\begin{array}{l}\text { Udder diseases } \\
\text { Choroby wymienia }\end{array}$ & 17 & 9.66 \\
\hline $\begin{array}{l}\text { Infertility and reproductive system diseases } \\
\text { Jałowość i choroby układu rozrodczego }\end{array}$ & 61 & 34.66 \\
\hline $\begin{array}{l}\text { Infectious diseases (including leukemia) } \\
\text { Choroby zakaźne (w tym białaczka) }\end{array}$ & 1 & 0.57 \\
\hline $\begin{array}{l}\text { Old age } \\
\text { Starość }\end{array}$ & 1 & 0.57 \\
\hline $\begin{array}{l}\text { Metabolic and alimentary system diseases } \\
\text { Choroby metaboliczne i układu pokarmowego }\end{array}$ & 25 & 14.20 \\
\hline $\begin{array}{l}\text { Respiratory system diseases } \\
\text { Choroby układu oddechowego }\end{array}$ & 4 & 2.26 \\
\hline $\begin{array}{l}\text { Locomotor system diseases } \\
\text { Choroby układu ruchu }\end{array}$ & 13 & 7.39 \\
\hline $\begin{array}{l}\text { Casualties } \\
\text { Wypadki losowe }\end{array}$ & 17 & 9.66 \\
\hline $\begin{array}{l}\text { Other } \\
\text { Inne }\end{array}$ & 13 & 7.39 \\
\hline$\sum$ & 176 & 100.00 \\
\hline
\end{tabular}

Regarding the incidence of reproductive health problems in cows during their reproductive life (Table 2) the total number of 396 such cases were recorded in the analysed period, with their cumulative percentage amounting to 22.68. In relation to the incidence rates of specific reproductive system disorders it was found that cows most frequently $(9.68 \%)$ suffered from endometritis, while relatively frequent cases were also recorded in the case of ovarian cysts $(6.70 \%)$ and hypoovarianism (3.21\%). Polycystic ovaries and spontaneous abortions accounted for $2.12 \%$ and $0.86 \%$ culling cases, respectively. Uterine tumour and pyometra each caused only one culling case.

Table 3 presents shares of reproductive system disorders during the reproductive period in terms of the division into primiparous and multiparous cows. Statistical analysis showed no effect of the age group of cows on the frequency of reproductive health disorders, while the 
determined strength of the dependence between the investigated traits was low (0.0507). It was found that primiparous cows in relation to multiparous cows were characterised by a comparable frequency of specific disorders during the reproductive period, whereas in some cases (hypoavarianism and polycystic ovaries) the incidence rate of these diseases in this age group even exceeded that in the group of older cows.

Table 2. Frequency of reproductive health problems in Jersey cows in the reproductive period in the analysed years

Tabela 2. Frekwencja występowania przypadków zaburzeń zdrowotnych układu rozrodczego krów rasy jersey $w$ okresie rozmnażania $w$ analizowanych latach

\begin{tabular}{|c|c|c|c|c|}
\hline $\begin{array}{l}\text { Health disorder } \\
\text { Zaburzenie zdrowotne }\end{array}$ & $\mathrm{N}$ & $\begin{array}{l}\text { Percentage } \\
\text { Procent }\end{array}$ & $\begin{array}{c}\mathrm{N} \\
\text { cumulative } \\
\text { skumulowany }\end{array}$ & $\begin{array}{c}\text { Percentage } \\
\text { cumulative } \\
\text { Procent } \\
\text { skumulowany }\end{array}$ \\
\hline $\begin{array}{l}\text { Endometritis } \\
\text { Zapalenie błony śluzowej macicy }\end{array}$ & 169 & 9.68 & 169 & 9.68 \\
\hline $\begin{array}{l}\text { Uterine tumors } \\
\text { Guz macicy }\end{array}$ & 1 & 0.06 & 170 & 9.74 \\
\hline $\begin{array}{l}\text { Hypovarianism } \\
\text { Niedoczynność jajników }\end{array}$ & 56 & 3.21 & 226 & 12.94 \\
\hline $\begin{array}{l}\text { Abortion } \\
\text { Poronienia }\end{array}$ & 15 & 0.86 & 241 & 13.80 \\
\hline $\begin{array}{l}\text { Pyometra } \\
\text { Ropomacicze }\end{array}$ & 1 & 0.06 & 242 & 13.86 \\
\hline $\begin{array}{l}\text { Ovarian cyst } \\
\text { Torbiel jajnika }\end{array}$ & 117 & 6.70 & 359 & 20.56 \\
\hline $\begin{array}{l}\text { Polycystic ovary } \\
\text { Wielokrotne cysty jajnika }\end{array}$ & 37 & 2.12 & 396 & 22.68 \\
\hline
\end{tabular}

Table 3. Shares of reproductive health problems in Jersey cows in the reproductive period in terms of division into primiparous and multiparous cows

Tabela 3. Udział zaburzeń zdrowotnych układu rozrodczego krów rasy jersey w okresie rozmnażania z uwzględnieniem pierwiastek i wieloródek

\begin{tabular}{|c|c|c|c|c|c|c|c|c|c|}
\hline \multirow{2}{*}{$\mathrm{N}$} & & \multicolumn{7}{|c|}{ Health disorders - Zaburzenia zdrowotne } & \multirow{2}{*}{$\Sigma$} \\
\hline & & END & GM & $\mathrm{NJ}$ & POR & ROP & $\mathrm{T}$ & WC & \\
\hline \multirow{4}{*}{$\begin{array}{l}\text { Primiparous } \\
\text { Pierwiastki }\end{array}$} & $\mathrm{N}$ & 65 & 1 & 23 & 5 & - & 47 & 18 & 159 \\
\hline & $\% 1$ & 40.88 & 0.63 & 14.47 & 3.14 & - & 29.56 & 11.32 & 100.00 \\
\hline & $\%^{2}$ & 38.46 & 100 & 41.07 & 33.33 & - & 40.17 & 48.65 & \\
\hline & $\mathrm{N}$ & 104 & - & 33 & 10 & 1 & 70 & 19 & 237 \\
\hline \multirow{2}{*}{$\begin{array}{l}\text { Multiparous } \\
\text { Wieloródki }\end{array}$} & $\%^{1}$ & 43.88 & - & 13.92 & & 0.42 & 29.54 & 8.02 & 100.00 \\
\hline & $\%^{2}$ & 61.54 & - & 58.93 & 4.22 & 100.00 & 59.83 & 51.35 & \\
\hline \multirow{2}{*}{$\Sigma$} & $\mathrm{N}$ & 169 & 1 & 56 & 15 & 1 & 117 & 37 & 396 \\
\hline & $\%^{2}$ & 100.00 & 100.00 & 100.00 & 100.00 & 100.00 & 100.00 & 100.00 & \\
\hline $\begin{array}{l}\text { Fisher's test } \\
\text { Test Fishera } \\
\text { Fobl. } \text { F }_{\text {tab. }}\end{array}$ & \multicolumn{9}{|c|}{0.7863} \\
\hline $\begin{array}{l}\text { Cramer's } \\
\text { coefficient } \\
\text { Współczynnik } \\
\text { Cramera }\end{array}$ & \multicolumn{9}{|c|}{0.0507} \\
\hline
\end{tabular}

$\%^{1}$ - percentage in row - procent $w$ wierszu; $\%^{2}$ - percentage in column - procent $w$ kolumnie.

${ }^{* *} \mathrm{P} \leq 0.01 ;{ }^{*} \mathrm{P} \leq 0.05$.

END - endometritis - zapalenie błony śluzowej macicy, GM - uterine tumors - guz macicy, NJ - hypoovarianism niedoczynność jajników, POR - abortion - poronienia, ROP - pyometra - ropomacicze, T - ovarian cyst - torbiel jajnikowa, WC - polycystic ovary - wielokrotne cysty jajnika. 


\section{DISCUSSION}

Results of these analyses showed that in Poland sterility is the primary cause for culling of dairy cows, while the frequency of this cause among all the culling cases seems to vary. In studies on Polish Black-and-White cattle with varying shares of Holstein-Friesian genes in the genome conducted by Chmielnik et al. (1991), Antkowiak and Kliks (1998), Gnyp et al. (1999), Sawa and Maciejewski (2000), Antkowiak et al. (2001), Skrzypek (2001) and Czaplicka et al. (2002) it was shown that the percentage of cows culled due to sterility ranged from $11.7 \%$ to 56.7\%. In later studies on Polish Holstein-Friesian cattle Kuczaj et al. (2008) and Pytlewski et al. (2010) stated that sterility and reproductive system diseases accounted for $34.2 \%$ and $40.67 \%$ all culling causes. In the opinion of Skrzypek (2001), reproductive disorders also constitute the first cause for culling in Jersey cows (21.3\%); however, its level in relation to that in Black-and-White cattle is by approx. $20 \%$ lower. In this study a higher culling rate (by $13.36 \%$ ) due to that cause was recorded. Problems with reproduction in cows are a derivative of multiple factors, among which a major role is played by inadequate nutrition. In many studies a deterioration of fertility was shown in cows with an increasing milk yield. This most probably results from greater problems with providing an optimal intake of nutrients in the feed ration for high-producing cows. Thus inadequate nutrition of cows at a specific lactation stage, at a predefined yield and in the dry period results in reproduction problems. A similar opinion was expressed by Khan et al. (2016), who claimed that the primary causes for low fertility of dairy cows are connected with inadequate nutrition and health management of these animals.

Uterine diseases have a very negative effect on the function of the body regarding fertility. One of them is the impaired growth and development of the ovarian follicle due to insufficient amount of hormone necessary to induce ovulation (estradiol). In this study endometritis was shown to be the most frequent reproductive system disorder in Jersey cows. This is a disorder which extends the interpregnancy period in cows. Mostly, during uterine inflammation, the fertilization does not occur, which is a consequence of a disorder of the uterine structure which should feed the embryo to its complete implantation. Inflammation of the uterus is a local infection of the lining of the uterus, which develops an inflammatory process that results in white oil discharge from the uterus to the vagina mixed with the mucus (Sheldon 2007). This disorder is usually a result of postnatal infections. Due to the intensity of the symptoms we distinguish four stages of uterine inflammation.

In their study Kasimanickam et al. (2004) stated that cows with subclinical endometritis were characterised by the threatened pregnancy risk index ranging from 0.49 to 0.59 in comparison to healthy cows. In turn, Simenov et al. (1984) showed that in cows with ketosis the frequency of endometriosis was 6-fold greater than in the control. In the opinion of Roche (2006), metabolic diseases predispose cows to gynecologic disorders, thus sterility is frequently associated with inadequate nutrition of dairy cows particularly in the periparturient period. Frequent causes for reproductive problems include also ovarian cysts, hypoovarianism and polycystic ovaries. Kübar and Jalakas (2002) stated that the primary cause of sterility $(85 \%)$ in culled Holstein-Friesian cows resulted from ovarian cysts. Studies conducted in Norway by Nelson et al. (2010) showed that the incidence rate of ovarian cysts in cows 
was $0.82 \%$ per lactation and the frequency of this disorder increased with successive lactations. Mösenfechtel et al. (2000) stated that cows with an excessively high body condition score were characterised by an increased frequency of ovarian cysts. In the opinion of Kesler and Garverick (1982) some cows are predisposed to this disorder and it is best to conduct selection by eliminating susceptible animals. Hatler et al. (2006) reported that a progesterone injection at an early stage of cyst development reduces its viability. As a result of long-term observations conducted for many years in Spain in herds of high-producing HF cows, Yániz et al. (2008) reported an increase in milk yields as well as an increase in the frequency of hypoovarianism, at a slight change in the incidence rate of ovarian cysts. Results reported by those authors suggest a dependence between productivity of cows and hypoovarianism. Kesler and Garverick (1982) reported that the frequency of polycystic ovaries in cows ranges from $6 \%$ to $19 \%$. However, in this study a lower frequency of this disorder was recorded in Jersey cows. Kadokawa and Martin (2006) were of an opinion that high milk yields in cows generate stress, which cause the incidence of metabolic and reproduction disorders. In the opinion of Bossaert et al. (2008), lipolysis in the transition period in cows is a factor delaying ovulation. According to Khan et al. (2016), the primary causes for low fertility of dairy cows are connected with inadequate nutrition and poor health management of the animals. Yániz et al. (2008) also showed that ovarian function and fertility were considerably deteriorated in the warm season, while the use of fans and water sprinklers during heat waves improved them. In the opinion of López-Gatius (2003), a cool environment promotes fertility and reduces the probability of sterility in cows irrespective of their milk yields. Flamenbaum and Galon (2010) claimed that in the summer season cows should be intensively cooled and their body temperature needs to be maintained at the normal level, since it affects the development of ovarian follicles and milk yield.

Norman et al. (2012) reported that the incidence of abortion in Holstein cows is higher $(1.32 \%)$ than in Jersey cows $(1.10 \%)$. Results of this study confirm this thesis.

Results of the study indicate a relatively low frequency of reproductive system disorders in Jersey cows in the analysed herd in the reproduction period. However, in order to reduce the frequency of these disorders environmental factors affecting these animals need to be continuously monitored and optimised.

\section{CONCLUSIONS}

1. Sterility and reproductive system disorders were the most frequent culling causes in Jersey cows.

2. It was shown that in the reproduction period endometritis was the most common reproductive system disease in Jersey cows.

3. No statistically significant relationship was found between the age group of cows (primiparous vs. multiparous cows) and the frequency of specific reproductive system disorders.

4. The incidence of reproductive system diseases in the reproduction period may be reduced in Jersey cows at a continuous improvement of environmental factors affecting these animals. 


\section{REFERENCES}

Antkowiak I., Kliks R. 1998. Intensywnosć i przyczyny brakowania krów o różnym genotypie [Intensity and causes of culling cows of different genotypes]. Rocz. AR Pozn., Zootech. 302(50), 9-14. [in Polish]

Antkowiak I., Pytlewski J., Stanisławski D. 2001. Intensywnosć i przyczyny brakowania krów w gospodarstwie farmerskim „Paruszewo" [Causes and inensity of culling cows in the „Paruszewo" farm]. Zesz. Nauk. PTZ 59, 67-77. [in Polish]

Bossaert P., Leroy J.L., De Viegher S., Opsomer G. 2008. Interrelations between glucose- induced response metabolic indicators and time of first ovulation high-yielding dairy cows. J. Dairy Sci. 91, 3363-3371.

Chmielnik H., Jankowska M., Rohde A. 1991. Długość użytkowania i przyczyny brakowania krów cb $\mathrm{z}$ różnym udziałem krwi hf [Lenght of performance and culling reasons of Black and White cows with different participation of HF blood]. Zesz. Nauk. PTZ 3, 51-55. [in Polish]

Czaplicka M., Puchajda Z., Szalunas T. 2002. Porównanie przyczyn brakowania krów importowanych z Francji z miejscową rasą cb [Comparision of reasons for culling hf cows imported from France with Polish BW cows]. Rocz. Nauk. Zootech. 15, Supl., 57-61. [in Polish]

Flamenbaum I., Galon N. 2010. Management of heat stress to improve fertility in dairy cows in Israel. J. Reprod. Dev. 56, Suppl., S36-41.

Gnyp J., Małyska T., Kamieniecki K., Kowalski P. 1999. Wpływ wydajności mleka pierwiastek czarno-białych na ich użytkowość mleczną, płodność i długość użytkowania w kolejnych latach [Effect of milk yield of Black-and-white primiparas on their milk performance, fertility and utilization lenght in successive years]. Zesz. Nauk. PTZ 44, 117-123. [in Polish]

Hatler T.B., Hayes S.H., Anderson L.H., Silvia W.J. 2006. Effect of single injection of progesterone on ovarian follicular cysts in lactating dairy cows. Vet. J. 172, 329-333.

Kadokawa H., Martin G.B. 2006. A new perspective on management of reproduction in dairy cows: the need for detailed metabolic information on improved selection index and extended lactation. J. Reprod. Dev. 52, 161-168.

Kasimanickam R., Duffield T.F., Foster R.A., Gartley C.J., Leslie K.E., Walton J.S., Johnson W.H. 2004. Endometrial cytology and ultrasonography for the detection of subclinical endometritis in postpartum dairy cows. Theriogenology 62, 9-23.

Kesler D.J., Garverick H.A. 1982. Ovarian cysts in dairy cattle: a review. J. Anim Sci. 55, 1147-1159.

Khan M.H., Manoj K., Pramod S. 2016. Reproductive disorders in dairy cattle under semi-intensive system of rearing in north-eastern India. Vet. World 9, 512-528.

Kuczaj M., Zielak A., Blicharski P. 2008. Reasons for the culling of Polish Holstein-Friesian cows in a high yield herd. Med. Weter. 64, 1205-1208.

Kübar H., Jalakas M. 2002. Pathological changes in the reproductive organs of cows and heifers culled because of infertility. J. Vet. Med. A Physiol. Pathol. Clin Med. 49, 366-372.

López-Gatius F. 2003. Is fertility declining in dairy cattle? A retrospective study in northeastern Spain. Theriogenology 60, 89-99.

Mösenfechtel S., Eigenmann U.J., Wanner M., Rüsch P. 2000. Rückenfettdicke und fruchtbarkeit bei braunvienkühen [Back fat thickness and fertility in Brown Swiss cows]. Schweiz Arch. Tierheilkd 142, 679-689. [in German]

Nelson S.T., Martin A.D., Østeräs O. 2010. Risk factors associated with cystic ovarian disease in Norwegian dairy cattle. Acta Vet. Scand. 52, 52-60.

Norman H.D., Miler R.H., Wright J.R., Hutchison J.L., Olson K.M. 2012. Factors associated with frequency of abortions recorded through dairy herd improvement test plans. J. Dairy Sci. 95, 4074-4084.

Pytlewski J., Antkowiak I., Staniek M., Skrzypek R. 2010. Intensity and causes of culling in Polish Black-and-White Holstein-Friesian cows. Ann. Anim. Sci. 10, 477-487. 
Roche J.F. 2006. The effect of nutritional management of the dairy cow in reproductive efficiency. Anim. Reprod. Sci. 96, 282-296.

SAS ${ }^{\circledR}$ user's guide. Statistics version 9.4 edition. 2015. SAS Institute, Cary, NC, USA.

Sawa A., Maciejewski P. 2000. Przyczyny brakowania krów w zalezności od poziomu produkcyjnego i liczebności stada w byłym województwie włocławskim w latach 1991-1998 [Reasons for culling cows in relations to the level of production and numer of cows in a herd in the former Włocławek District in 1991-1998]. Zesz. Nauk. PTZ 51, 171-176. [in Polish]

Sheldon M. 2007. Zdrowa macica - zdrowa ferma [Healthy uterus - healthy farm]. Hod. Głową 3, 47-52. [in Polish]

Simenov S., Petrova L., Tsvetkova V. 1984. Effect of ketosis on the reproductive process in high-yield cows. Vet. Med. Nauki 21, 89-93.

Skrzypek R. 1994. Jersey: Status and perspectives. World Jersey Cattle Bureau 1, 3.

Skrzypek R. 2001. Charakterystyka cech funkcjonalnych u bydła rasy jersey [Characterization of functional characteristics in jersey cattle]. Prz. Hod. 10, 7-10. [in Polish]

Yniz J., López-Gatius F., Bech-Sábat, Garcia-Ispierto I., Serrano B., Santolaria P. 2008. Relationships between milk production, ovarian function and fertility in high-producing dairy herds in north-eastern Spain. Reprod. Domest Anim. Suppl. 4, 38-43.

Zając-Mazur M. 2007. Stopień brakowania krów mlecznych jako miara efektywności pracy hodowlanej [Culling level of dairy cows as a measure of breeding work efficiency in the herd]. Wiad. Zootech. 45(3), 15-17. [in Polish]

\begin{abstract}
The aim of this study was to analyse culling causes and determine reproductive health disorders in Jersey cows in the reproduction period in a herd from the Wielkopolska region. Analyses were conducted on 331 Jersey cows. The material for analyses was collected for the years 2010-2015 from the performance records of dairy cows, the AfiFarm herd management programme and veterinary inspection records. Source data concerned causes of cow culling and reproductive system disorders found in the reproduction period (i.e. from calving to successful fertilisation). Culling causes were divided based on the criterion applied by the Polish Federation of Cattle Breeders and Dairy Farmers. In this study the shares of culling causes were determined and the frequency of individual reproductive system disorders in the reproduction period were calculated in terms of the division into primiparous and multiparous cows. Sterility and reproductive system disorders were the most frequent culling causes in Jersey cows. In turn, endometritis was the most frequent reproductive disorder in cows of this breed in the reproduction period. No statistically significant relationship was found between the age group of cows (primiparous vs. multiparous) and the frequency of specific reproductive system disorders. The incidence rate of reproductive system disorders in Jersey cows in the reproduction period may most probably be reduced at a continuous improvement of environmental factors affecting these animals.
\end{abstract}

